Collection: NFZ Summer School 2009 - Birmensdorf (Switzerland)

Long-term ecosystem research: understanding the present to shape the future

Guest Editor: Marcus Schaub (WSL, Switzerland)

\section{Separating soil respiration components with stable isotopes: natural abundance and labelling approaches}

\author{
Braig $\mathrm{E}^{(1)}$, Ťupek $\mathrm{B}^{(2)}$
}

Due to the potential of forest ecosystems contributing to $\mathrm{CO}_{2}$ increase as well as to climate change mitigation, forest-atmosphere $\mathrm{CO}_{2}$ exchange has been intensively studied over last decades. However, the contribution of individual components of belowground carbon pools is still poorly known. In particular, there is no unequivocal means to separate root respiration (autotrophic) from heterotrophic respiration by soil microflora and fauna. Most studies investigating soil respiration disturbed the soil and tried to exclude autrophic respiration. Here we review alternative non invasive methods to separate the two components. Those methods share the application of the stable carbon isotope ${ }^{13} \mathrm{C}$, using either local changes in natural abundance of ${ }^{13} \mathrm{CO}_{2}$ or artificial labelling of trees with $\mathrm{CO}_{2}$ enriched or depleted in ${ }^{13} \mathrm{C}$. We conclude that the applicability of natural stable isotope methods is still limited in forest ecosystems because only in a few cases there are large enough differences in ${ }^{13} \mathrm{C}$ among soil carbon pools (usually due to the earlier presence of a $\mathrm{C}_{4}$ canopy, which is seldom in forests). On the other hand, artificial labelling with $\mathrm{CO}_{2}$ either enriched or depleted in ${ }^{13} \mathrm{C}$ is now in a widely used for partitioning soil respiration components. However, recent findings gave clear evidence that measurements of soil $\mathrm{CO}_{2}$ efflux can be substantially influenced by the return efflux of the abiotic label. Still, especially the combination of Free Air Carbon Enrichment (FACE) with dual $\delta^{13} \mathrm{C}$ and $\delta^{18} \mathrm{O}$ stable isotope approach has the potential to provide new answers on the response sensitivity of turnover dynamics of the largest belowground soil carbon storage to elevated temperature and $\mathrm{CO}_{2}$.

Keywords: Carbon stable isotopes, Labelling, Natural abundance, Autotrophic and heterotrophic soil respiration

\section{Introduction}

Soil respiration is the largest component of ecosystem respiration (Ryan \& Law 2005) and therefore a key element in the carbon source/sink role especially for forest ecosystems. The ongoing increase in both atmospheric temperature and $\mathrm{CO}_{2}$ content has an

(1) Technical University Munich, Dept. Limnologische Station Iffeldorf, Hofmark 1 3, D-82393 Iffeldorf (Germany); (2) Dept. Forest Ecology, University of Helsinki, Latokartanonkaari 7, FI-00014 Helsinki (Finland)

\section{@, Emanuel Braig (emanuelbraig@web.de)}

Received: May 25, 2010 - Accepted: May 31, 2010

Citation: Braig E, Ťupek B, 2010. Separating soil respiration components with stable isotopes: natural abundance and labelling approaches. 3: 92-94 [online: 2010-07-15] URL: http://www.sisef.it/iforest/show.php? id $=541$ enhancing effect on the flux of $\mathrm{CO}_{2}$ from soil respiration (Heimann \& Reichstein 2008). In spite of the increased soil respiration flux with elevated air temperature and $\mathrm{CO}_{2}$ level, the individual components of soil respiration [autotrophic root respiration, heterotrophic microbial respiration, and litter and soil organic matter (SOM) degradation] remain difficult to quantify. This is a challenging quest because all existing methods (Kuzyakov 2006) bear their respective limitations. Promising new insights have been obtained et al. 2006, Millard et al. 2008, Søe et al. 2004), where either: a) natural variability in the abundance of carbon isotopes in different compartments is examined; or b) a labelled ${ }^{13} \mathrm{CO}_{2}$ signal is applied to compartments of the soil carbon cycle.

The aims of this mini review are firstly to present the main idea behind selected stable isotope approaches, namely: a) the method of natural ${ }^{13} \mathrm{C}$ abundance; $\mathrm{b}$ ) the method of from the use of stable carbon isotopes (Crow isotopic labelling with ${ }^{13} \mathrm{C}$-depleted $\mathrm{CO}_{2}$; and (c) the method of isotopic labelling with ${ }^{13} \mathrm{C}$ -enriched $\mathrm{CO}_{2}$. The second aim is to evaluate the methods' applicability for the separation of the autotrophic and heterotrophic components of soil respiration in field conditions.

\section{Method of natural abundance}

The heavier stable isotope ${ }^{13} \mathrm{C}$ is much less abundant than the lighter ${ }^{12} \mathrm{C} .{ }^{13} \mathrm{C} \approx 1.10 \%$ of the total carbon (Farquhar \& Richards 1984). The isotopic carbon signature of any material is reported in the delta notation $\left(\delta^{13} \mathrm{C}\right)$ with per mil (\%o) units, which refers to the ratio between the isotopic ${ }^{13} \mathrm{C} /{ }^{12} \mathrm{C}$ ratio (R) of the sample to the international reference $\mathrm{V}$ PDB standard (eqn. 1):

$$
\delta^{13} C=1000 \cdot \frac{R_{\text {sample }}}{R_{\text {standard }}}(\% o)
$$

where a higher $\delta^{13} \mathrm{C}$ stands for more heavy stable isotopes than the standard (enrichment) and a lower $\delta^{13} \mathrm{C}$ means less heavy stable isotopes than the standard (depletion). It is this ratio that is of particular interest for plant ecology as it is altered / fractionated to a varying degree by the different photosynthetic metabolisms of $\mathrm{C}_{3}$ and $\mathrm{C}_{4}$ plants. Because of differences in $\mathrm{CO}_{2}$ uptake and therefore different rates of diffusive fractionation, tissue of $\mathrm{C}_{3}$ plants will be isotopically depleted by about $-29 \%$ (Kuzyakov 2006), while $\mathrm{C}_{4}$ plant tissue shows a depletion of only $-13 \%$ as compared to the standard. Numerous processes (Scartazza et al. 2004) including physiological status and meteorological conditions can influence these averaged values, but still these differences afford an excellent starting-point for separating soil respiration components by natural abundances of isotopes in the case where a $\mathrm{C}_{3}$ canopy follows a $\mathrm{C}_{4}$ crop (or vice versa) (Yakir \& Sternberg 2000). Up to now, this is still an important limitation in the applicability of the natural abundance approach in forests, because $\mathrm{C}_{3}$ and $\mathrm{C}_{4}$ substitutions involving trees are rare. In the original forest without $\mathrm{C}_{3}$ and $\mathrm{C}_{4}$ substitutions, only small differences in the isotopic signal of soil respiration components were found in laboratory experiments. These differences might be diminished by the great spatial variability of soil efflux isotopic signal found in situ (Formánek \& Ambus 2004).

Formánek \& Ambus (2004) were able to distinguish $\delta^{13} \mathrm{C}$ of $\mathrm{CO}_{2}$ efflux from root-free mineral horizons, root-free humus layer and roots. The $\delta^{13} \mathrm{C}$ signatures alone were not sufficient to separate contributions of root respiration and SOM decomposition in the forest soil $\mathrm{CO}_{2}$ efflux measured in the field. The necessary estimate of root-free respiration profile $\delta^{13} \mathrm{C}$ signature was roughly calculated by bulk densities related contribution 
of each layer to the total $\mathrm{CO}_{2}$ efflux. Therefore, the estimation of $43 \%$ of root from total soil respiration could be realistic, but needs to be considered with caution, although it falls into the $29-59 \%$ range as reported by other carbon isotopic studies of temperate mixed deciduous forests (Borken et al. 2006 , Gaudinski et al. 2000).

\section{Method of isotopic labelling}

There are two main labelling processes available: (i) labelling with ${ }^{13} \mathrm{C}$-depleted $\mathrm{CO}_{2}$ originating from fossil fuel combustion; (ii) labelling with ${ }^{13} \mathrm{C}$-enriched $\mathrm{CO}_{2}$ produced by nuclear processes.

The isotopic signature of air $\mathrm{CO}_{2}$ is $-8.00 \%$ o at present (Bowling et al. 2008), but continuously moves towards more negative values because of fossil $\mathrm{C}$ combustion. $\mathrm{CO}_{2}$ derived from fossil carbon sources, i.e., mineral oil and coal, shows a depleted carbon isotopic signature of about $-35.00 \%$ (Lin et al. 1999), which turns it in an ideal and inexpensive substrate for isotopic labelling of the soil carbon cycle under both field and enclosed conditions. There are many ongoing and already conducted isotopic labelling studies (e.g., Allen et al. 2000) with very promising results, but in the present paper we focus on one particular work by Lin et al. (1999), because this study achieved clear partitioning of three forest soil respiration components (i.e., $\mathrm{CO}_{2}$ efflux from root, litter, and SOM). In this study, 4-year old Douglas-fir trees were grown under controlled conditions in terracosms with four different combinations of ambient and elevated $\mathrm{CO}_{2}$ concentrations and temperature. $\mathrm{SOM}$ and soil litter originated not from the present trees but from an old growth Douglas-fir forest. In both the elevated and ambient groups, a constant $\mathrm{CO}_{2}$ concentration was maintained by fumigating the terracosms with tank $\mathrm{CO}_{2}$. The tank $\mathrm{CO}_{2}$ fumigation resulted in newly formed plant material such as needles and roots with a $\delta^{13} \mathrm{C}$ of $-35.77 \pm 0.09 \%$ o ( \pm standard deviation $)$ compared to an atmospheric $\mathrm{CO}_{2} \quad \delta^{13} \mathrm{C}$ of $-8.55 \pm 0.13 \%$ in the area where SOM as well as the organic litter of the soil in use had formed. With this approach alone, it would have not been possible to separate the three main components of soil respiration and to understand their individual responses to elevated temperature and $\mathrm{CO}_{2}$, because $\mathrm{CO}_{2}$ both from SOM and litter degradation carrying the same carbon isotopic signal. Lin et al. (1999) found an elegant solution to this problem: they took advantage of the information in the $\delta^{18} \mathrm{O}$ oxygen isotopic signature in the soil respired $\mathrm{CO}_{2}$ molecule, which is in equilibrium with the respective signature in soil water. When soil water evaporation occurs, there is a diffusive fractionation of the water molecules carrying the two different stable oxygen isotopes ${ }^{16} \mathrm{O}$ and ${ }^{18} \mathrm{O}$. This isotopic enrichment of ${ }^{18} \mathrm{O}$ takes place only in the upper $10 \mathrm{~cm}$ of soil which allows a separation of $\mathrm{CO}_{2}$ originating from litter degradation and $\mathrm{CO}_{2}$ from SOM degradation according to their respective oxygen isotopic signature. The disadvantages of this particular approach apply as well for other labelling studies, i.e., FACE. In most cases, the task of maintaining constant conditions results in an elevated $\mathrm{CO}_{2}$ concentration. This means a major disturbance to the ecosystem carbon flux, because in the supply to microbial communities, the intricate relation between the supply of fresh energy abundant carbon compounds (leaf litter, rhizo-exudates and rhizo-deposition) and old, more nutrient prone soil organic carbon is altered (Paterson et al. 2009). The need to label some components limits the applicability of the method under field conditions, even if a main focus is put on maintaining ambient conditions concerning the $\mathrm{CO}_{2}$ concentration.

A very interesting example of isotopic labelling with enriched ${ }^{13} \mathrm{CO}_{2}$ is the study of Subke et al. (2009) conducted on stand scale in a naturally regenerated Pinus silvestris forest in northern Sweden. Subke et al. (2009) pulse-labeled (3h) the trees in two chambers (each $200 \mathrm{~m}^{3}$ ) with highly enriched ${ }^{13} \mathrm{CO}_{2}$ and monitored the resulting ${ }^{13} \mathrm{CO}_{2}$ soil efflux with a combination of deep, root free and surface collars over a period of 6 days. In this setup, the isotopic ${ }^{13} \mathrm{C}$ signature of deep collars excluded plant derived $\mathrm{CO}_{2}$. The authors were able to separate the initial physical ${ }^{13} \mathrm{CO}_{2}$ flux caused by the direct tracer diffusion from the atmosphere and the later occurring biological ${ }^{13} \mathrm{CO}_{2}$ flux caused by root respiration of photosynthates (biotic label return). Approximately 2-3 days after pulse labelling, only in deep collars ${ }^{13} \mathrm{CO}_{2}$ returned from the initial peak to near natural abundance, while in surface collars, ${ }^{13} \mathrm{CO}_{2}$ likely from the respiration of labelled assimilates allocated below-ground, increased again and reached the maximum ca. 3.5-4 days after the pulse. In spite of the separation of autotrophic pulse-derived ${ }^{13} \mathrm{CO}_{2}$ tracer from the difference between surface collars and deep collars, the experiment was primarily designed to separate abiotic and biotic tracer returns. However, the method has the potential for separating the autotrophic and heterotrophic part of soil $\mathrm{CO}_{2}$ efflux, if the experimental design allows plant photosynthesis to use only the labelled ${ }^{13} \mathrm{C}$ enriched $\mathrm{CO}_{2}$ source.

\section{Conclusions}

In this mini review, we compared the use of natural abundance and labelled carbon isotope methods in partitioning forest soil autotrophic and heterotrophic respiration components. The natural abundance carbon isotope method has the potential of separating forest soil respiration components, al- though its applicability is limited to situations where overplanting from $\mathrm{C}_{4}$ to $\mathrm{C}_{3}$ plants occurred. On forest sites with an exclusive $\mathrm{C}_{3}$ vegetation history, the individual soil components must be physically isolated (disturbing the carbon cycle). In addition, natural $\delta^{13} \mathrm{C}$ signatures show high spatial variation allowing only for a rough partitioning of soil respiration. The difficulty of relying on the existing $\mathrm{C}_{4} \mathrm{SOM}$ can be overcome by the tank fumigation with ${ }^{13} \mathrm{C}$-depleted or ${ }^{13} \mathrm{C}$-enriched $\mathrm{CO}_{2}$. The newly formed organic material with depleted or enriched ${ }^{13} \mathrm{C}$ signatures enables to distinguish the root autotrophic respiration from heterotrophic respiration of litter, roots and SOM formed before labelling with natural abundance ${ }^{13} \mathrm{CO}_{2}$. However, also long-term fumigation experiments require an exclusion of the roots for a separation of the components of autotrophic soil respiration. A step further to non-invasive separation of autotrophic and heterotrophic components was achieved by the combination of long-term fumigation with dual $\delta^{13} \mathrm{C}$ and $\delta^{18} \mathrm{O}$ stable isotope tracers. Isotopic methods advanced from the disturbance of carbon cycle to a less invasive approach achieved by the combination of the former accomplishments. If a virtually undisturbed partitioning of the forest soil respiration components into fast and slow carbon turnover would be possible, it would enable better opportunities to study the effects of both elevated temperature and $\mathrm{CO}_{2}$ concentration onto the balance of long-term soil carbon storage.

\section{Acknowledgements}

We want to thank the whole team of the WSL summer school 2009, especially Dr. Marcus Schaub, not only for making this work possible but also for a warm welcome to Zurich and for an enlightening week. We are grateful to three reviewers for their valuable comments on an earlier version of this manuscript. We also want to express our gratitude to our supervisors and institutions for their support.

\section{References}

Allen AS, Andrews JA, Finzi AC, Matamala R, Richter DD, Schlesinger WH (2000). Effects of free-air $\mathrm{CO}_{2}$ enrichment (FACE) on belowground processes in a Pinus taeda forest. Ecological Applications 10 (2): 437-448. - doi: 10.1890/10510761(2000)010[0437:EOFACE]2.0.CO;2

Bowling DR, Pataki DE, Randerson JT (2008). Carbon isotopes in terrestrial ecosystem pools and $\mathrm{CO}_{2}$ fluxes. New Phytologist 178: 24-40. doi: 10.1111/j.1469-8137.2007.02342.x

Borken W, Savage K, Davidson EA, Trumbore SE (2006). Effects of experimental drought on soil respiration and radiocarbon efflux from a temperate forest soil. Global Change Biology 12: 177-193. - doi: 10.1111/j.1365-2486.2005. 001058.x 
Crow SE, Sulzman EW, Rugh WD, Bowden RD, Lajtha K (2006). Isotopic analysis of respired $\mathrm{CO}_{2}$ during decomposition of separated soil organic matter pools. Soil Biology and Biochemistry 38 (11): 3279-3291. - doi: 10.1016/j.soilbio.2006.04.007

Farquhar GD, Richards RA (1984). Isotopic composition of plant carbon correlates with water-use efficiency of wheat genotypes. Australian Journal of Plant Physiology 11: 539-552 - doi: 10.1071/PP9840539

Formánek P, Ambus P (2004). Assessing the use of ${ }^{13} \mathrm{C}$ natural abundance in separation of root and microbial respiration in a Danish beech (Fagus sylvatica L.) forest. Rapid Communications in Mass Spectrometry 18 (8): 897-902. doi: $10.1002 / \mathrm{rcm} .1424$

Gaudinski JB, Trumbore SE, Davidson EA, Zheng, S (2000). Soil carbon cycling in a temperate forest: radiocarbon-based estimates of residence times, sequestration rates and partitioning of fluxes. Biogeochemistry 51: 33-69. - doi: 10.1023/A:1006301010014

Heimann M, Reichstein M (2008). Terrestrial ecosystem carbon dynamics and climate feedbacks. Nature 451 (7176): 289-292. - doi: 10.1038/ nature06591

Kuzyakov Y (2006). Sources of $\mathrm{CO}_{2}$ efflux from soil and review of partitioning methods. Soil Biology and Biochemistry 38 (3): 425-448. - doi: 10.1016/j.soilbio.2005.08.020

Lin GH, Ehleringer JR, Rygiewicz PT, Johnson MG, Tingey DT (1999). Elevated $\mathrm{CO}_{2}$ and temperature impacts on different components of soil $\mathrm{CO}_{2}$ efflux in Douglas-fir terracosms. Global Change Biology 5 (2): 157-168. - doi: 10.1046/j.1365-2486.1999.00211.x

Millard P, Midwood AJ, Hunt JE, Whitehead D, Boutton TW (2008). Partitioning soil surface $\mathrm{CO}_{2}$ efflux into autotrophic and heterotrophic components, using natural gradients in soil ${ }^{13} \mathrm{C}$ in an undisturbed savannah soil. Soil Biology and Biochemistry 40 (7): 1575-1582. - doi: 10.1016/ j.soilbio.2008.01.011

Paterson E, Midwood AJ, Millard P (2009). Through the eye of the needle: a review of isotope approaches to quantify microbial processes mediating soil carbon balance. New Phytologist 184 (1): 19-33. - doi: 10.1111/j.1469-8137.2009. 03001.X

Ryan MG, Law BE (2005). Interpreting, measuring, and modeling soil respiration. Biogeoche- mistry: 3-27. - doi: 10.1007/s10533-004-5167-7

Scartazza A, Mata C, Matteucci G, Yakir D, Moscatello S, Brugnoli E (2004). Comarisons of delta $\mathrm{C}-13$ of photosynthetic products and ecosystem respiratory $\mathrm{CO}_{2}$ and their response to seasonal climate variability. Oecologia 140 (2): 340351. - doi: 10.1007/s00442-004-1588-1

Søe ARB, Giesemann A, Anderson TH, Weigel HJ, Buchmann N (2004). Soil respiration under elevated $\mathrm{CO}_{2}$ and its partitioning into recently assimilated and older carbon sources. Plant and Soil 262 (1): 85-94. - doi: 10.1023/B:PLSO. $0000037025.78016 .9 \mathrm{~b}$

Subke J-A, Vallack HW, Magnusson T, Keel SG, Metcalfe DB, Högberg P, Ineson P (2009). Short-term dynamics of abiotic and biotic soil ${ }^{13} \mathrm{CO}_{2}$ effluxes after in situ ${ }^{13} \mathrm{CO}_{2}$ pulse labelling of a boreal pine forest. New Phytologist 183 (2): 349-357. - doi: 10.1111/j.1469-8137.2009.02883. $\mathrm{x}$

Yakir D, Sternberg LSL (2000). The use of stable isotopes to study ecosystem gas exchange. Oecologia 123 (3): 297-311. - doi: 10.1007/ s004420051016 